\title{
Efek Moderasi Dukungan Sosial Dalam Hubungan Konflik Pekerjaan Keluarga Dengan Stres Kerja Dosen Wanita Di Fakultas Ekonomi Undiksha
}

\author{
N. M. D. A. Mayasari \\ Jurusan Manajemen, Universitas Pendidikan Ganesha, Singaraja \\ e-mail: dwi.mayasari@undiksha.ac.id,
}

\begin{abstract}
Abstrak
Penelitian ini bertujuan untuk mengetahui efek moderasi pemberian dukungan sosial dalam hubungan konflik pekerjaan keluarga dengan stres kerja dosen wanita di Fakultas Ekonomi Undiksha. Responden dari penelitian ini sebanyak 28 orang dosen wanita yang telah berkeluarga. Metode yang digunakan adalah dengan penyebaran kuisioner dan wawancara mendalam. Hasil tabulasi data dianalisis dengan metode ANOVA memakai bantuan program SPSS versi 17 for windows. Hasil analisis diperoleh hasil bahwa konflik pekerjaan keluarga berpengaruh terhadap stres dosen wanita di Fakultas Ekonomi Undiksha. Hasil analisis moderasi memperoleh hasil bahwa dukungan sosial yang diberikan kepada dosen wanita baik dukungan sosial rendah maupun dukungan sosial tinggi mampu menurunkan stres yang dialami oleh dosen wanita di Fakultas Ekonomi Undiksha.
\end{abstract}

Kata Kunci: Dukungan Sosial, Konflik Pekerjaan Keluarga, Stres Kerja

\section{Abstract}

This study aims to determine the moderating effect of providing social support in the relationship of family work conflict with work stress of female lecturers at the Faculty of Economics Undiksha. Respondents from this study were 28 female lecturers who were married. The method used is the distribution of questionnaires and in-depth interviews. The results of the data tabulation were analyzed by the ANOVA method using SPSS version 17 for windows. The results of the analysis showed that the conflict of family work affected the stress of female lecturers at the Faculty of Economics Undiksha. The results of the moderation analysis found that social support provided to female lecturers, both low social support and high social support, was able to reduce the stress experienced by female lecturers at the Faculty of Economics Undiksha

Keywords : Family Work Conflict, Social Support, Work Stress

\section{Pendahuluan}

Perubahan demografi tenaga kerja terhadap peningkatan jumlah wanita bekerja dan pasangan yang keduanya bekerja, telah mendorong terjadinya konflik antara pekerjaan dan kehidupan keluarga. Greenhaus dan Beutell (1985) dalam Yang et al (2000) mendefinisikan konflik pekerjaan keluarga (work family conflict) sebagai bentuk konflik peran di mana tuntutan peran pekerjaan dan keluarga secara mutual tidak dapat disejajarkan dalam beberapa hal. Konflik ini terjadi ketika seseorang berusaha memenuhi tuntutan peran dalam pekerjaan dan usaha tersebut dipengaruhi oleh kemampuan individu yang bersangkutan untuk memenuhi tuntutan keluarganya. Konflik peran ini akan terjadi ketika pemenuhan tuntutan peran dalam keluarga dipengaruhi oleh kemampuan orang tersebut dalam memenuhi tuntutan pekerjaannya (Frone \& Copper, 1992). Tuntutan pekerjaan berhubungan dengan tekanan yang berasal dari beban kerja yang berlebihan dan deadline atau tengat waktu pekerjaan yang harus diselesaikan. Sedangkan tuntutan keluarga berhubungan dengan waktu yang dibutuhkan untuk menangani tugas-tugas rumah tangga. Tuntutan keluarga ini ditentukan oleh besarnya keluarga, komposisi keluarga dan jumlah anggota keluarga yang memiliki ketergantungan terhadap anggota yang lain (Yang, et al,2000).

Stress kerja dapat dipandang dari dua sisi yaitu sisi positif dan sisi negatif. Stress yang dikonotasikan sebagai sesuatu yang negatif disebut distress, sedangkan stress yang memberikan dampak positif disebut eustress. Dampak positif stress pada tingkat rendah 
sampai pada tingkat moderat bersifat fungsional berperan sebagai motivasi diri, rangsangan untuk bekerja keras dan inspirasi untuk meningkatkan kehidupan yang lebih baik. Sedangkan pada dampak negatif stress pada tingkat yang tinggi menyebabkan penurunan kinerja karyawan secara drastis (Gitosudarmo dan Sudita, 1997).

Menurut Gibson, et al (1991), definisi stimulus stress merupakan suatu kekuatan atau perangsang yang menekan individu dan menimbulkan tanggapan (respon) terhadap ketegangan (strain). Dalam definisi tersebut terdapat adanya suatu ketidakjelasan mengenai akibat yang ditimbulkan oleh tingkat stress yang sama pada individu yang berbeda, atau dengan kata lain definisi stimulus hanya melihat pada aspek stress atau tekanan saja, tanpa melihat akibat yang akan terjadi. Definisi respon memandang stress sebagai tanggapan fisiologis atau psikologis dari seseorang terhadap tekanan lingkungannya, dimana stress sebagian besar berasal dari lingkungan dari luar diri individu. Berdasarkan definisi tersebut dapat dinyatakan bahwa stress adalah suatu stimulus yang berupa tekanan dan mempengaruhi kondisi fisik maupun psikologis individu, dimana tekanan atau stimulus tersebut dapat berasal dari dalam diri individu maupun di luar individu

Manusia membutuhkan orang lain untuk dapat memenuhi kebutuhannya dalam kehidupan sehari-hari. Hubungan antar karyawan dibutuhkan untuk menyelesaikan tugastugas dalam lingkungan pekerjaan. Ada dua alasan penting keberadaan dukungan sosial.

1. Individu membutuhkan bantuan orang lain bilamana tujuan atau aktivitas pekerjaan demikian luas dan kompleks sehingga tidak dapat menyelesaikannya sendirian.

2. Hubungan antara karyawan mempunyai nilai sebagai tujuan yaitu pekerjaan yang menuntut hubungan saling membantu.

Dukungan sosial adalah suatu transaksi interpersonal yang melibatkan affirmation atau bantuan dalam bentuk dukungan instrumen yang diterima individu sebagai anggota jaringan sosial (House dan Wells, 1987 dalam Russell et al, 1989).

Fakultas Ekonomi Universitas Pendidikah Ganesha (Undiksha) merupakan salah satu penyelenggara pendidikan jenjang Strata 1 (S1) dan Diploma 3 (D3). Tuntutan akan kualitas atau mutu pendidikan merupakan kewajiban yang harus dipenuhi oleh Fakultas Ekonomi Undiksha. Perwujudan itu dilakukan dalam bentuk penyediaan sarana yang memadai dan Sumber Daya Manusia (SDM) yang bekualitas. Guna mewujudkan hal tersebut, Fakultas Ekonomi Undiksha secara perlahan-lahan terus memperbaiki diri untuk meningkatkan kualitasnya.

Usaha peningkatan itu tidak serta merta dapat dicapai dengan baik. Keterbatasan Sumber Daya Manusia (SDM) khususnya dosen menjadi salah satu perhatian saat ini. Jumlah dosen yang dimiliki saat ini oleh Fakultas Ekonomi Undiksha belum memadai. Hal itu memicu tingginya jam mengajar setiap dosen yang rata-rata 22 SKS (Sistem Kredit Semester) setiap minggunya. Disamping itu tuntutan melaksanakan tri dharma perguruan tinggi lainya seperti penelitian dan pengabdian kepada masyarakat (PKM) harus tetap dilaksanakan

Tuntutan yang cukup tinggi dari profesi tersebut tak jarang menimbulkan stres bagi para dosen khususnya dosen wanita yang memiliki peran ganda. Satu sisi berperan sebagai dosen, sisi lainya berperan sebagai orang tua yang ikut mengurus keluarga. Tuntutan yang harus dipenuhi oleh desen wanita mulai dari mengajar, memberikan bimbingan kepada mahasiswa, melakukan penelitian, dan melaksanakan pengabdian kepada masyarakat (PKM) memyebabkan tingginya beban kerja yang berpotensi menyebabkan stress kerja (Isnovijanti,2002). Disamping beban kerja dari profesinya, dosen wanita juga harus mengurus keluarga mereka yang berkibat bertambahnya stres yang dialami.

Selain beban kerja sebagai dosen dan beban mengurus keluarga, stres juga dipicu oleh konflik peran ganda yang dialami. Tidak jarang dalam melaksanakan pekerjaan sebagai dosen mereka mengalami konflik-konflik baik dengan atasan,rekan kerja, maupun dengan mahasiswa. Sikap diremehkan rekan kerja, dan perlakuan-perlakuan yang tidak disenangi sangat sering memicu konflik di dalam menjalani profesi mereka sebagai dose. Dalam rumah tangga juga tak jarang mereka mengalami konflik dengan anggota keluarganya. Konflik dengan suami, dan konflik dengan anak-anak cukup tinggi memicu bertambahnya stres. 
Fenomena ini menunjukkan keterlibatan wanita sebagai SDM dalam angkatan kerja dan hal ini akan membawa dampak terhadap kehidupan keluarganya. Beberapa faktor yang menjadi penyebab partisipasi wanita dalam dunia kerja adalah faktor ekonomi dan non ekonomi. Selain faktor ingin memperoleh pendapatan, wanita yang bekerja didorong pula oleh keinginan untuk berkembang, memperoleh kepuasan dari pekerjaan, dan aktualisasi kemampuan, serta perasaan bangga akan diri dan kemandirian (walaupun penghasilan suami mencukupi). Kondisi dari adanya pasangan karier ganda (two career couple) akan menimbulkan masalah dalam hal mengelola pekerjaan dan tanggung jawab keluarga. Apabila keseimbangan tidak diperoleh maka akan menimbulkan konflik pekerjaan keluarga.

Penelitian ini akan menuji efek moderasi dukungan social dalam hubungan konflik pekerjaan keluarga dan stress kerja. Hasil penelitian nantinya diharapkan mampu menjawab permasalahan stress kerja yang dialami oleh dosen wanita di Fakultas Ekonomi Undiksha.Penelitian terdahulu umumnya mengangkat responden yang bergelut di dunia kesehatan, sedangkan penelitian ini akan mengangkat responden yang berbeda dengan karakteristik responden pada penelitian sebelumnya, responden dalam penelitian ini dosen wanita di Fakultas Ekonomi Undiksha yang telah berkeluarga.

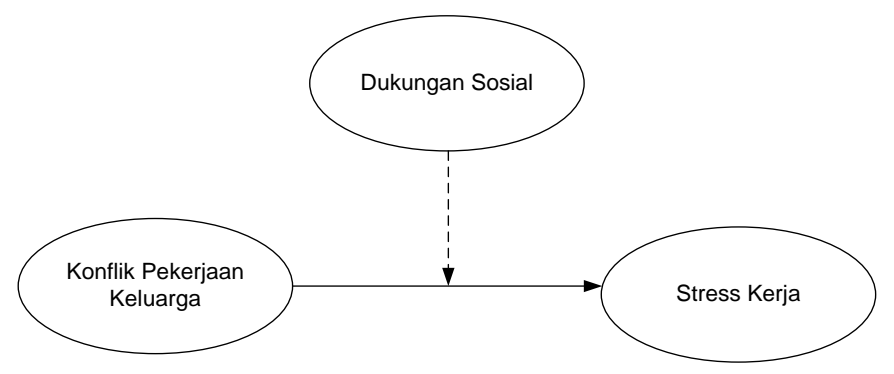

Gambar 1. Moderasi Dukungan Sosial Dalam Hubungan Konflik Pekerjaan Keluarga Dengan Stres Kerja

\section{Metode}

Jenis data yang digunakan dalam penelitian ini adalah data kuantitatif, yaitu data yang dinyatakan dalam bentuk angka-angka yang dapat dihitung dan data kualitatif, yaitu data yang tidak dapat dinyalakan dalam bentuk angka-angka. Populasi adalah wilayah generalisasi yang terdiri atas objek atau subjek yang mempunyai kualitas dan karakteristik tertentu yang ditetapkan oleh peneliti untuk dipelajari dan kemudian ditarik kesimpulannya (Sugiyono, 2005). Responden dalam penelitian ini 28 orang dosen wanita yang sudah berkeluarga di Fakultas Ekonomi Undiksha

Instrumen penelitian atau alat pengumpul data yang akan digunakan dalam penelitian ini berupa kuesioner sering disebut angket merupakan daftar pernyataan yang diberikan langsung kepada responden untuk diisi. Sedangkan dalam pengukuran datanya memakai Skala Likert (Sugiyono, 2005). Dengan skala ini responden diminta memberikan respon terhadap setiap pernyataan dengan memilih dari rentang skala 1 sampai 5.

Pengujian validitas item pengukuran dilakukan dengan metode analisis faktor, ekstraksi dilakukan berdasarkan metode principle axis factoring untuk memperoleh 1 faktor. Faktor yang terbentuk harus memiiki nilai eigen minimal 1,0, dan nilai total variance explained 0,50 . Item-item yang dipertahankan dalam skala adalah item yang memiliki nilai faktor loading minimal 0,50 ( Hair, Anderson, Tatham \& Balck, 1998).

Reliabilitas adalah pengukuran derajat konsistensi antara beberapa ukuran dari sebuah variabel. Uji Reliabilitas bertujuan untuk mengetahui kestabilan dan tingkat konsistensi alat ukur yang digunakan dalam mengukur sebuah konsep. Untuk menguji tingkat reliabilitas, biasanya digunakan Cronbach's Coeficient Alpha yang mengindikasikan seberapa jauh itemitem dalam penelitian tersebut saling berkorelasi positif satu dengan lainnya. Nilai Cronbach's Alpha berkisar antara 0 sampai 1. Semakin dekat Cronbach's Alpha mendekati nilai 1,0, maka semakin baik reliabilitas alat ukur tersebut. Ada tiga kategori reliabilitas 
mengacu pada nilai Cronbach's Alpha, yaitu ; $0,8-1,0$ : reliabilitas baik, 0,6 - 0,79: reliabilitas diterima, dan $<0,6$ : reliabilitas buruk.

Pengujian hipotesis penelitian dilakukan dengan metode analisis ANOVA faktorial univariat. ANOVA (Analysis of Variance) adalah pengujian statistik untuk menguji hipotesis nol bahwa beberapa populasi mempunyai rata-rata yang sama. Jogiyanto (2008) menyatakan beberapa kriteria yang harus diperhatikan dalam menggunakan ANOVA adalah sebagai berikut.

1. Dependen variabel harus variabel bernilai kontinyu.

2. Sampel dan data harus berdistribusi normal.

3. Sampel harus diambil secara random dari populasi-populasinya.

4. Populasi-populasi harus mempunyai varian-varian yang sama.

5. 5) Kesalahan residu dari masing-masing nilai harus independent (Independence of error) yaitu jarak satu nilai dengan rata-rata groupnya harus independen terhadap jarak nilai-nilai lainya terhadap ratarata groupnya tersebut.

Pengujian statistik dilakukan dengan bantuan perangkat lunak SPSS versi 17.0. Analisis deskriptif menjelaskan nilai skor masing-masing variabel dependen yakni intensi keluar pada masing-masing faktor sel. Analisis deskriptif dilakukan untuk mendeskripsikan hasil pengukuran masing-masing variabel penelitian dalam besaran statistik seperti skor rerata (mean), nilai tengah (median), frekuensi terbesarnya (modus) dan simpangan baku (standar deviasi

\section{Hasil dan Pembahasan \\ Validitas dan Reliabilitas}

Hasil analisis data menyatakan bahwa sebanyak 14 (empat belas) item pernyataan mengenai stress kerja memiliki nilai faktor loading lebih besar dari 0,5 dengan nilai Keisser Olkin Meyer (KMO) lebih besar dari 0,5, commulative explained variance lebih besar dari 50 persen dan nilai cronbach's alpha diatas 0,7 . Sebanyak 14 (empat belas) item pernyataan mengenai variabel stres kerja dosen wanita dinyatakan valid dan reliabel.

Hasil analisis data menyatakan dari 10 (sepuluh) item hanya 9 (sembilan) pernyataan mengenai konflik pekerjaan keluarga memiliki nilai faktor loading lebih besar dari 0,5 , nilai Keisser Olkin Meyer (KMO)lebih besar dari 0,5, commulative explained variance lebih besar dari 50 persen dan nilai cronbach's alpha diatas 0,7 . Berdasarkan nilai tersebut dinyatakan bahwa sebanyak satu pernyataan tidak valid dan reliabel.

Berdasarkan hasil analisis menyatakan bahwa sebanyak 12 (dua belas) item pernyataan dukungan sosial memiliki nilai faktor loading lebih besar dari 0,5 , nilai Keisser Olkin Meyer (KMO)lebih besar dari 0,5, commulative explained variance lebih besar dari 50 persen dan nilai cronbach's alpha diatas 0,7. Berdasarkan nilai tersebut dinyatakan dinyatakan valid dan reliabel.

Hasil

\section{Pengaruh Konflik Pekerjaan Keluarga Terhadap Stres Kerja}

Hasil analisis data diperoleh nilai $F=60,884$ dengan nilai signifikansi $p=0,000<0,05$. Hasil analisis menunjukkan signifikan sehingga hipotesis 1 diterima. Hal ini mengandung arti bahwa konflik pekerjaan keluarga berpengaruh secara signifikan terhadap stres kerja dosen wanita di Fakultas Ekonomi Undiksha

\section{Pengujian Efek Moderasi Dari Dukungan Sosial}

Hasil analisis ANOVA univariat menunjukkan adanya efek interaksi konflik pekerjaan keluarga dengan dukungan sosial sebagai variabel moderasi terhadap stress kerja, dosen wanita di Fakultas Ekonomi Undiksha hal ini dinyatakan signifikan dengan nilai $F(3,71)=$ $5,153, p=0,008<0,05$. Nilai tersebut mengandung makna adanya perbedaan stres kerja diantara kelompok dosen wanita di Fakultas Ekonomi Undikshayang memiliki konflik pekerjaan keluarga yang berbeda dengan pemberian dukungan sosial yang berbeda pula.

.Data parameter estimasi menunjukkan bahwa efek dukungan sosial dan konflik pekerjaan keluarga dibentuk oleh persamaan regresi berikut: 


$$
\text { Stres Kerja }=51,250+9,550(K)+3,645(K)(D S 1)+3,125(K)(D S 2)
$$

Data parameter estimasi menunjukkan nilai $B 2=3,645, t=3,209$, sig $=0,002$. Nilai ini mengandung arti bahwa ada perbedaan stres kerja secara signifikan antara kelompok dosen wanita yang memiliki konflik pekerjaan rendah dengan dukungan sosial rendah dibandingkan dengan kelompok dosen wanita yang memiliki konflik pekerjaan keluarga rendah dengan dukungan sosial tinggi.

Data parameter estimasi menunjukkan nilai $\beta_{3}=3,125, t=1,908$ sig $=0,024$. Nilai tersebut menunjukkan adanya perbedaan stress kerja antara kelompok dosen wanita yang memiliki konflik pekerjaan keluarga tinggi dengan dukungan sosial yang rendah dibandingkan dengan kelompok dosen wanita yang memiliki konflik pekerjaan keluarga tinggi dengan dukungan sosial yang tinggi.

Hasil analisis secara keseluruhan dapat dinyatakan bahwa dukungan sosial mampu menurunkan stres kerja dosen wanita di Fakultas Ekonomi Undiksha baik yang memiliki konflik pekerjaan keluarga rendah maupun konflik pekerjaan keluarga tinggi. Ini artinya dukungan sosial memgoderasi hubungan konflik pekerjaan keluarga dengan stres kerja secara signifikan.

\section{Pembahasan}

\section{Konflik Pekerjaan Keluarga Terhadap Stres Kerja}

Konflik pekerjaan keluarga pada dosen wanita cenderung mengarah pada stress kerja ketika urusan pekerjaan mencampuri kehidupan keluarga, tekanan seringkali terjadi pada individu untuk mengurangi waktu yang dihabiskan dalam pekerjaan dan menyediakan lebih banyak waktu untuk keluarga. Sama halnya dengan konflik keluarga pekerjaan dapat mengarah pada stress kerja dikarenakan banyaknya waktu untuk berkumpul bersama keluarga menyebabkan kurangnya waktu yang dibutuhkan dalam menangani urusan pekerjaan. Dosen wanita yang mengalami tingkat konflik pekerjaan keluarga yang tinggi akan mempunyai tingkat depresi yang tinggi sehingga mengarah pada stress kerja, tingkat kemangkiran kerja meningkat dan produktivitas menjadi berkurang.

Hasil ini sejalan dengan penelitian yang dilakukan oleh Khan, et al dalam Linda Thomas dan Ganster (1995) menjelaskan bahwa konflik pekerjaan keluarga merupakan salah satu bentuk konflik antar peran, tekanan untuk menyeimbangkan antara tanggung jawab keluarga dan pekerjaan tersebut dapat menyebabkan timbulnya stress. Cinamon et al (2002), menyatakan hal yang serupa dengan Khan bahwa konflik pekerjaan keluarga akan mengarahkan para guru akan timbulnya stress kerja. Para guru akan berusaha mengatasi permasalahan yang timbul akibat keluarga maupun pekerjaan pemicu terjadinya konflik pekerjaan keluarga dan stress kerja pada akhirnya. Penelitian Cinamon ini sejalan dengan penelitian yang dilakukan oleh Chew (2002) menjelaskan bahwa para guru yang mengajar di SMP Kaoshiung bahwa merawat anak merupakan faktor pemicu tertinggi terjadinya konflik pekerjaan keluarga dan adanya campur tangan keluarga dalam urusan pekerjaan merupakan faktor utama dari stress kerja.

Pada konteks penelitian ini, stres kerja dosen wanita timbul disebabkan peran ganda yang dimainkan wanita baik sebagai dosen yang harus melaksanakan tri dharma perguruan tinggi maupun sebagai ibu yang harus mengurus keluarga. Beban mengajar yang cukup tinggi akan banyak menghabiskan dosen wanita bekerja lebih lama untuk mengajar di kampus. Disamping itu setiap dosen juga dituntut untuk melakukan penelitian dan pengabdian kepada masyarakat (PKM) yang biasanya dilakukan diluar lingkungan kampus. Tentu hal ini memakan waktu dari proses perencanaan, turun kelapangan (survey), studi pustaka, maupun membuat laporanya. Tak jarang beberapa dosen wanita harus membawa pekerjaanya pulang kerumah sehingga mengambil waktu berkumpul bersama keluarga.

Sebagai seorang ibu rumah tangga, mereka dituntut pula untuk mengerjakan pekerjaan rumah yang tidak sedikit. Mulai dari menyiapkan kebutuhan makanan, kebersihan rumah maupun kebutuhan lainya, tentu memerlukan waktu untuk mengerjakanya. Tak jarang konflik pekerjaan keluarga muncul akibat situasi dimana dosen wanita tersebut harus mengerjakan pekerjaanya sebagai dosen dirumah yang membuat waktu bersama keluarga dan mengerjakan pekerjaan rumah semakin berkurang. Komplain dari anggota keluarga 
karna semakin berkurangnya waktu kebersamaan atau terbengkalainya pekerjaan rumah menyebankan konflik sering terjadi yang berakiat semakin tingginya sres yang dialami. Begitu juga sebaliknya, dosen wanita yang menyelesaikan pekerjaan rumahnya akan mengurangi waktu kerja dikampus. Sering dijumpai dosen wanita lebih lama menyelesaikan tugas dari pekerjaan yang harus diselesaikan seperti laporan penelitian dan laporan pengabdian kepada masyarakat (PKM). Keterlambatan ini menyebabkan rekan kerja atau atasan mengejar-ngejar mereka untuk menyelesaikan pekerjaanya sehingga menyebabkan terjadinya konflik yang berujung stres menjadi lebih tinggi.

\section{Moderasi Dukungan Sosial}

Berdasarkan hasil analisis secara total bahwa dukungan sosial dapat menurunkan stress kerja, hal ini menunjukkan tingkat stress yang dialami oleh dosen wanita di Fakultas Ekonomi Undiksha dapat diatasi melalui dukungan sosial dari berbagai sumber. Hasil penelitian menemukan bahwa dukungan sosial dapat memoderasi konflik pekerjaan keluarga dosen wanita rumah Fakultas Ekonomi Undiksha dalam menurunkan tingkat stress kerja yang dialaminya. Hasil ini mendukung temuan dari Linda dan Ganster (1995) yang menekankan akan pentingnya dukungan sosial dalam menurunkan tingkat stress kerja yang dialami oleh karyawan dengan adanya konflik pekerjaan keluarga. Hasil penelitian ini sejalan dengan penelitian yang dilakukan oleh beberapa peneliti sebelumnya, Russell (1987) menunjukkan bahwa dukungan sosial yang diterima oleh karyawan dapat mengurangi stress kerja dan burn out pada profesi guru. Penelitian serupa dilakukan pula oleh Deeter (1997) dimana hasil penelitiannya menunjukkan adanya hubungan negatif antara dukungan sosial dengan stress kerja atau dengan kata lain tingginya dukungan sosial menyebabkan rendahnya stress kerja, karena melalui dukungan sosial individu dapat mengatasi stress.

Dukungan social yang diberikan kepada dosen wanita bisa dilakukan dari sisi keluarga maupun pekerjaan. Konflik pekerjaan keluarga yang dialami baik itu rendah maupun tinggi akan mampu menurunkan tingkat stres dosen wanita jika dukungan sosial yang diberikan dapat diterima oleh mereka. Ketika dosen wanita mengalami konflik dalam lingkungan pekerjaanya, maka peran keluarga untuk memberikan dukungan sosial perlu ditingkatkan. Membantu menyelesaikan pekerjaan rumah oleh anggota keluarga lainya dapat membantu meringankan stres yang dialami dosen wanita. Begitu juga sebaliknya, ketika konflik keluarga dialami oleh dosen wanita atasan maupun rekan kerja bisa meringankan stres yang dialami seperti memberikan semangat, membantu menyelesaikan pekerjaan kampus, maupun memberikan waktu lebih lama kepada mereka untuk menyelesaikan pekerjaanya. Peran dukungan sosial untuk menurunkan stres yang diakibatkan oleh konflik keluarga pekerjaan bisa dilakukan oleh keluarga maupung lingkungan pekerjaan

\section{Simpulan dan Saran}

Berdasarkan hasil pembahasan sebelumnya, maka dapat disimpulkan sebagai berikut. 1. Konflik pekerjaan keluarga yang dialami oleh dosen wanita di Fakultas Ekonomi Undiksha berpengaruh secara signifikan terhadap stress. Hasil ini membuktikan bahwa konflik pekerjaan keluarga yang dialami oleh dosen wanita di Fakultas Ekonomi Undiksha merupakan salah satu dari faktor pemicu timbulnya stress kerja dosen di rumah sakit BaliMed Denpasar. 2. Dukungan sosial terhadap dosen wanita di Fakultas Ekonomi Undiksha yang mengalami konflik pekerjaan keluarga dapat menurunkan tingkat stress kerja yang dialaminya. Pemberian dukungan sosial dengan tingkat yang berbeda (rendah dan tinggi) pada kelompok dosen wanita yang mengalami konflik pekerjaan keluarga rendah maupun tinggi memiliki perbedaan terhadap stress kerja yang dialaminya secara signifikan.Ini memiliki arti bahwa pemberian dukungan sosial yang berbeda akan memberikan pengaruh yang berbeda dalam menurunkan tingkat stress.

Beberapa saran yang dapat diungkapkan adalah sebagai berikut. 1. Dukungan sosial yang berasal dari atasan mampu menanggulangi stress kerja yang diakibatkan adanya konflik pekerjaan keluarga pada dosen. Dukungan sosial ini dapat dilakukan melalui penciptaan hubungan profesional yang tidak kaku, akrab, memperhatikan, dan mengayomi para dosen yang menjadi bawahannya, tidak bersikap otoriter sebagai atasan sehingga dosen tidak takut untuk bersikap terbuka terhadap atasan. Dengan demikian akan terjadi 
interaksi antara dosen dengan atasan yang harmonis. Melakukan pembinaan dosen secara profesional, artinya melakukan serangkaian usaha bantuan kepada dosen terutama bantuan yang berwujud layanan profesional guna meningkatkan proses dan pelayanan pendidikan yang menyenangkan, melalui seminar atau training (pelatihan atau lokakarya yang terkait dengan pengajaran, pengembangan diri dan profesi). 2. Dukungan sosial dari keluarga juga sangat diperlukan untuk menurunkan stress yang dialami. Hubungan keakraban yang baik, ditambah saling pengertian akan kondisi masing-masing anggota akan menciptakan suasana rumah yang nyaman bagi penghuninya.

\section{Daftar Pustaka}

Chew, Shu-Chin. 2002. Investigating the Relationship of Work Family Conflicts Through the Self Determination Theory. www.yahoo.com. Electronical Theses Heap of NSYSU, June $20^{\text {th }} 2002$.

Cinamon,G. Rachell. 2002. Gender Differences in the Importance of Work and Family Roles:Implications for Work-Family Conflict. http://www. FindsArticles.com:1-21.

Deeter, D.R., dan Ramsey, RP., 1997. Considering Source and Types of Social Support : A Psychometric Evaluation of the House and Wells (1978)Instrument. Journal of Personal Selling and Sales Management, Vol. XVII, No.1.1997.

Frone, Russell dan Cooper, 1992. Relationship Between Job and Family Satisfaction. Journal of Management, 565-579.

Gibson, J.L., Ivancevich, J.M., Donnelly, Jr., J.H., 1991, Organisasi: Perilaku, Struktur, Proses (Terj.), Penerbit Erlangga, Jakarta.

Gitosudarmo \& Suditta, 1997. Perilaku Keorganisasian. Yogyakarta : Erlangga.

Hair, Joseph F., Anderson, Rolph E., Tatham, Ronald L., dan Black, William C. 1998. Multivariate Data Analisis, Fifth Ediion, Prentice Hall International.

Isnovijanti, T. 2002. Pengaruh Dukungan Sosial Terhadap Stress Kerja Dan Kepuasan Kerja (Studi Kasus : Polres Pati Polda Jateng). Tesis Magister Manajemen Universitas Diponegoro tidak dipublikasikan.

Jogiyanto, 2008. Metodologi Penelitian Sistem Informasi. Yogyakarta : Penerbit ANDI

Linda Thomas \& Ganster, 1995. Impact of Family-Supportive Variables on Work-Family Conflict and Strain : A Control Perspective. Journal of Applied Psychology, Vol.80, No.1, p:6-15.

Russell, Daniel W; Altmaier. 1987. Job-related Stress, Social Support, and Burnout Among Classroom Teachers. Journal of Applied Psychology, Vol.72, No.2, p:269-274.

Sugiyono, 2005. Metode Penelitian Administrasi. Bandung : PT. Alfabeta

Yang, Nini, Chen Cao \& Zou Zimin. 2000. "Source of Work Family: Sino-US. Comparison of The Effect of Work and Family Demand". Academy ofManagement Journal, Vol. 43: 113-123. 